\title{
Prediction of Colorectal Cancer Driver Genes from Patients' Genome Data
}

(Penentuan Gen Pemandu Kanser Kolorektum daripada Data Genomik Pesakit)

\author{
MuHAmmad-IQMAl ABDUllaH \& Nor AZlan Nor MUHAMMAD*
}

\section{ABSTRACT}

Colorectal cancer refers to the cancer that occurs in the colon and rectum. It has been established as the third most common cancer and the forth one in causing worldwide mortality. Cancer caused by the mutation of several genes that usually involved in the regulation of cell proliferation, growth and cell death. The mutation that leads to abnormal function of genes, either in enabling the genes to gain or loss of function was termed as driver mutation and the genes with driver mutation ability was termed as driver genes. The identification of driver genes provides insight on mechanistic process of cancer development where this information can be used to further understand their mode of action for causing dysregulation in signaling pathways. In this study, two bioinformatic tools, i.e. CGI and iCAGES were used to predict potential driver genes from the genome of eight colorectal cancer patients with annotated variants datasets. 44 unique driver genes and 21 pathways have been identified; such as p53 signaling, PI3K-AKT, Endocrine resistance, MAPK and cell cycle pathways. The identification of these pathways can lead to the identification of potential drugs targeting these pathways.

Keywords: Cancer driver genes; colorectal cancer; pathway analysis; precision medicine

\section{ABSTRAK}

Kanser kolorektum adalah kanser yang berlaku pada kolon dan juga rektum. Ia merupakan kanser ketiga yang paling kerap dilaporkan serta yang keempat menjadi punca kematian tertinggi di seluruh dunia. Kanser berlaku disebabkan oleh mutasi daripada gen tertentu yang terlibat di dalam pengawalaturan proliferasi, pertumbuhan dan kematian sel. Mutasi yang mencetuskan perubahan pada fungsi gen sama ada meningkatkan atau menghilangkan fungsinya dikenali sebagai mutasi pemandu, manakala gen yang mempunyai mutasi pemandu dikenali sebagai gen pemandu kanser. Pengenalpastian gen pemandu membolehkan mekanisme pembentukan kanser dapat dikenal pasti melalui peranannya dalam pengawalaturan tapak jalan. Dalam kajian ini, dua perisian bioinformatik iaitu CGI dan iCAGES telah digunakan untuk mengenal pasti calon gen pemandu daripada set data varian yang telah dianotasi daripada genom lapan pesakit kanser kolorektum. Sebanyak 44 gen pemandu dan 21 tapak jalan terlibat telah dikenal pasti; antaranya adalah tapak jalan pengisyaratan p53, PI3K-AKT, rintangan endokrin dan MAPK. Kesemua tapak jalan ini berpotensi untuk dijadikan sasaran terapi.

Kata kunci: Analisis tapak jalan; gen pemandu kanser; kanser kolorektum; perubatan jitu

\section{INTRODUCTION}

Colorectal cancer (CRC) is the third most common cancer involving 2.4 million people per year worldwide. According to the age-standardized rate, the incidence of colorectal cancer in Malaysia showed higher occurrence in men by 20.9 cases per 100,000 compared to in women at 16.8 per 100,000 populations (Chye et al. 2008). Majority of the cases occurred in Chinese ethnic followed by the Malays and Indians (Radzi et al. 2016). Dietary habit has been listed as a main factor that affects intestinal macro and microenvironment. Consumption of food that affects the intestinal lining gave rise to the development of polyps. It was due to the harmful chemicals that are able to penetrate the cells and disturb genome stability by a process known as mutation (Kanner 2007; O'Keefe 2016; Ryan-Harshman $\&$ Aldoori 2007). The examples of bad dietary habit include consumption of carcinogenic foods, lack of dietary fiber in the diet that lead to the intestinal bleeding as well as a disturbance to the microbiome environment and probiotic metabolisms (Louis et al. 2014).

Consumption of food high in fiber enables gut microbiota to produce short-chain fatty acid such as butyrate during fermentation. Butyrate has an antiinflammatory and antineoplastic properties; and it can also provide the best energy source for colonocytes. Therefore, the risk of intestinal bleeding will be reduced as inflammation is suppressed by the anti-inflammatory substances produced by gut microbiota. Imbalance diet such as high consumption of protein and fat will produce substances with carcinogenic effects such as branched fatty acids that may induce inflammation and hydrogen sulfide that could cause DNA damage and lead to mutation if the repair mechanism is disrupted (O'Keefe 2016). These mutations may eventually affect the genes that are 
necessary to regulate cellular growth and to maintain the balance of cell proliferation.

Cancer driver genes are defined as genes that provide selective advantage for the cell to grow more rapidly as the proliferation and death-escaping characteristics of the cell are enhanced. These properties enable cells to grow more rapidly than their neighbouring cell in a specific condition and environment (Tokheim et al. 2016). Cancer driver genes such as APC (adenomatous polyposis coli) gene plays a critical role in regulating Wnt signaling pathway that responsible for cell proliferation. APC forms a destruction complex with several other proteins to inhibit $\beta$-catenin, a protein that activates Wnt signaling and preventing the cells to proliferate continuously. Mutation in APC may affect its function to perform destruction complex and unable to control cell proliferation (Kwong \& Dove 2009; Zhan et al. 2017). Driver genes can be mutated at both protein coding and non-coding regions but more commonly at the protein coding region. This mutation causes abnormal function of the genes and is known as driver mutation (Foo et al. 2015). The term 'driver' is introduced to distinguish it from a passenger gene that does not contribute to any abnormal cell growth. Passenger genes could be any genes or recorded as driver genes in TCGA database, however does not carry any driver mutation that affect their structure and function (Marx 2014).

Identification of cancer driver genes is one of the important aspects in whole genome sequencing projects. Two prominent consortiums working on the collection of cancer genes data are Cancer Genome Atlas (TCGA) and International Cancer Genome Consortium (ICGC). The top driver genes that currently reported contribute to colorectal carcinogenesis are APC, TP53 and KRAS. APC acts as tumor suppressor that form 'destruction complex' with Axin and GSK-3 $\beta$ to degrade $\beta$-Catenin in Wingless (Wnt) signaling pathway. Mutation which could lead to loss function of APC allows $\beta$-catenin keep acting as signal to promote cell proliferation through Wnt signaling pathway (Alberts 2008; Kwong \& Dove 2009). TP53 is activated by cellular stresses including DNA damage and acts as tumor suppressor that bind to regulatory regions of downstream target genes to induce cell cycle arrest, DNA repair and apoptosis (Iacopetta et al. 2006). Inactivation of TP53 is associated with later stage in cancer as the role of TP53 as an important upstream key regulator to control the number of cancer cells through apoptosis become malfunction (Rivlin et al. 2011). Proto-oncogene is a gene that normally has a role in activating or continuing cell proliferation, growth and differentiation activity. Mutation in this type of genes could lead to gain of function and transform proto-oncogenes to new role in driving cancer known as oncogenes. Oncogene such as KRAS could drive the cancer through mutation at specific binding sites. This could prevent KRAS to degrade and enable the pathways continuously run to induce cell growth and proliferation.
Precision medicine in cancer requires the information of cancer driver genes in order to perform specific therapy to target altered function of component in signaling pathways. Genes like KRAS has been targeted through biologic agents like cetuximab and panitumumab in clinical trials (Tan \& Du 2012).

Various bioinformatics tools for driver genes prediction have been developed to provide analysis tools for tumor sequencing project to distinguish driver and passenger genes; amongst other are SIFT (Sorting Intolerants from Tolerant) and Polyphen 2 (Polymorphism Phenotyping v2) (Adzhubei et al. 2015; Sim et al. 2012), HotNet2, MUFFINN (Mutations For Functional Impact on Network Neighbors) (Cho et al. 2016; Leiserson et al. 2014) and MuSIC (Mutational Significance in Cancer) (Dees et al. 2012). Here, two computational methods were used, i.e. Integrated Cancer Genome Score (iCAGES) and Cancer Genome interpreter (CGI). Both tools allowed for a single patient-based data analysis in determining high confidence prediction on driver genes via a combination of different tools that use different concept of systematic approaches.

iCAGES analyses the impact of variants using the scores obtained from eleven prediction tools that predict the impact of variants on the protein structure and function. Identification of cancer driver genes uses radial support vector machine (radial svm), a machine learning algorithm that combines all scores from the prediction tools. These tools were SIFT, PolyPhen 2, GERP++, Mutation Assessor, SiPhy, LRT, PhyloP, FATHMM, Mutation Tester, CADD and VEST. Driver gene prioritization unified radial SVM score with other bioinformatic tool known as Phenolyzer that predicts driver genes based on the oncogenicity of point coding mutation. Linear regression (LR) model is built to determine driver gene score with 0.11 as binary cut off for suggested cancer driver genes.

CGI determine the characteristics of cancer driver genes through the classification of genes based on their tumorigenic mode (Oncogene or Tumor Suppressor). Functional impact according to types of mutation, and occurrence among human population. CGI search and match query variants with TCGA database of cancer genes. Variants with no matches in TCGA library will undergo protein affecting mutation (PAM) assessment by algorithm known as Oncodrive-MUT. Oncodrive-MUT was built based on the random forest machine learning and classification algorithm that separate driver and passenger genes mutation by 0.78 accuracy based on Matthews Correlation Coefficient.

\section{MATERIALS AND METHODS}

\section{DATA SOURCE}

Variant annotated datasets (VCF) were obtained from eight patients (patient identification: C187, C194, C273, C373, C404, C414, C449, C474) involved in the CRC patient genome sequencing project led by UKM Medical Molecular 
Medicine Institute (UMBI). Illumina Hiseq $(30 \times$ coverage) was used for the sequencing and Gene Analysis Toolkit (GATK) was used in variant calling.

\section{PREDICTION OF CRC DRIVER GENE USING BIOINFORMATICS TOOLS}

Data were filtered by selecting all variants that occur at the exonic region as they are required as input in both tools. In iCAGES, the analysis was performed via http:// icages.wglab.org/ using hg19 as a reference genome. The required input format consists of the information on the chromosome, coordinates, references and alternate nucleotides. The output for the driver genes prediction consists of a list of genes with radial SVM score, funseq, cnv, phenolyzer and iCAGES gene score. As this analysis was focused on the nonsynonymous variants that occur at the coding region, the funseq and cnv scores were set at 0 and not included in the driver genes prediction. Predicted driver genes with gene score more than 0.11 were selected for the comparison with CGI results.

CGI analysis was performed on https://www. cancergenomeinterpreter.org and colon adenocarcinoma was selected as a reference for the cancer type. The input files must include all information on the chromosomes, coordinates and nucleotide changes. The genes that are stated as a driver should consist of tumor suppressor genes where loss of function is detected and oncogenes which gain of function is likely to be occurred in certain variants. In this analysis, consensus results from both tools were

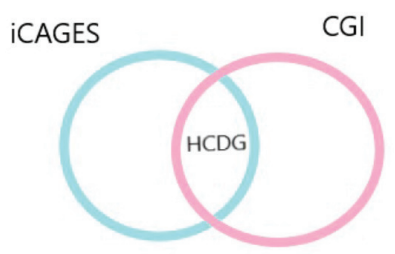

FIGURE 1. Selection of high confidence driver genes (HCDG) was based on the consensus result by iCAGES and CGI chosen and considered as highly confidence predicted driver genes (HCDG) (Figure 1).

\section{PATHWAY ANALYSIS}

KEGG MAPPER in combination with the information obtained from the bibliomic search were applied in identifying all pathways related to the predicted driver genes (Figure 2). Pathway mapping was performed using relevant KEGG pathway as a template in mapping the genes and to visualize the pathways that are likely to be affected by the driver genes was done using Cytoscape ver 3.6.0. Gene symbol of unique driver genes were set as an input in KEGG Mapper and the results were downloaded in KGML format for visualization.

\section{RESULTS AND DISCUSSION}

\section{CANCER DRIVER GENES PREDICTION}

The consensus predicted genes obtained from iCAGES and CGI were named as high confidence driver genes (HCDG). Forty-four HCDG were identified using our approach (Table 1). With this approach too, we have identified some genes that previously have not been listed in TCGA COADREAD and CGC Colorectal cancer genes dataset and have not been previously reported to be associated with colorectal cancer. Those genes were NCOR2, STAG2, PTPN12, TSC2, MYH9, NCOR1, PTCH1, ATF2 and ERBB3. These genes are potential candidates for newly identified colorectal cancer driver genes.

\section{PATHWAYS ASSOCIATED WITH PREDICTED DRIVER GENES}

Nonsynonymous variants that occurred at the exonic region were selected as an input for iCAGES and CGI. Predicted driver genes from both tools were named as HCDG (high confidence driver genes) and their respective pathways were identified from KEGG database and literature (Table 2).

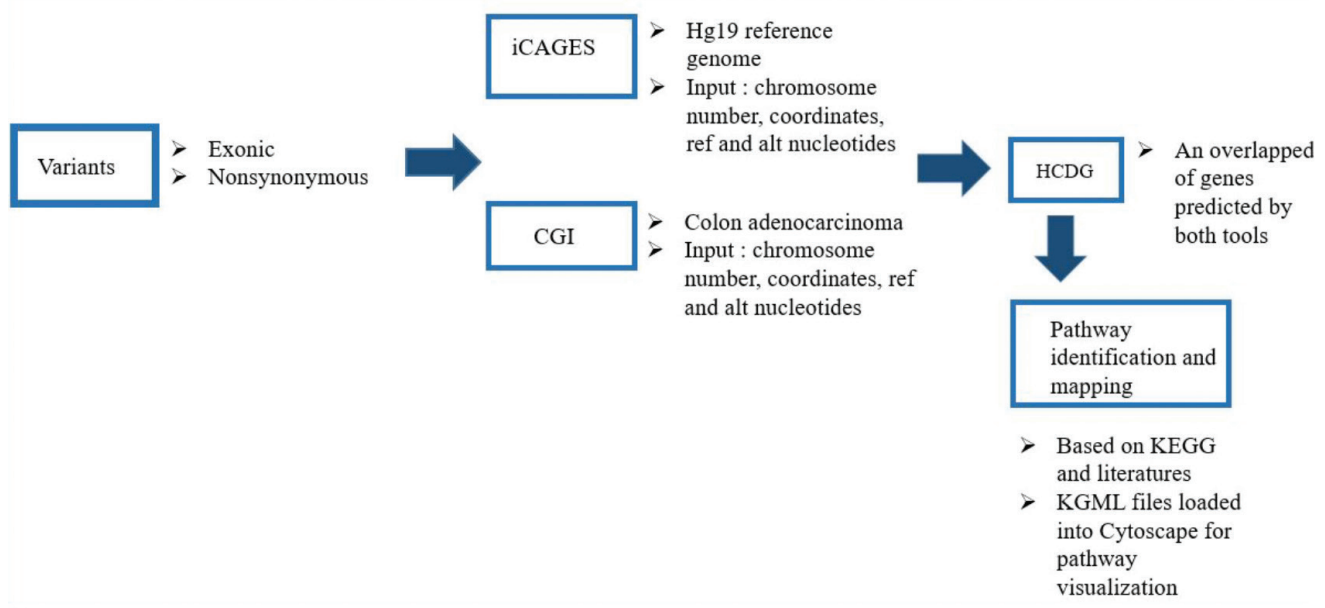

FIGURE 2. A flowchart for the prediction of colorectal cancer driver genes 
TABLE 1. Consensus predicted genes obtained from iCAGES and CGI methods are considered as highly confident driver genes (HCDG). Genes with bold characters are CRC driver genes listed in TCGA-COADREAD. Genes with * sign are listed in CGC as CRC driver genes

\begin{tabular}{|c|c|c|c|c|c|c|c|c|c|}
\hline & Patient ID & C187 & C194 & $\mathrm{C} 273$ & C373 & C404 & $\mathrm{C} 414$ & C449 & C474 \\
\hline & \multicolumn{9}{|l|}{ Gene name } \\
\hline 1 & TP53* & & & & & & & & \\
\hline 2 & $F B X W 7^{*}$ & & & & & & & & \\
\hline 3 & POLR $2 B^{*}$ & & & & & & & & \\
\hline 4 & $S R G A P 3^{*}$ & & & & & & & & \\
\hline 5 & $S M C 1 A$ & & & & & & & & \\
\hline 6 & KRAS* & & & & & & & & \\
\hline 7 & ITSN1 & & & & & & & & \\
\hline 8 & TCF $7 L 2 *$ & & & & & & & & \\
\hline 9 & CUL1 & & & & & & & & \\
\hline 10 & ARIDIA* & & & & & & & & \\
\hline 11 & $B R A F^{*}$ & & & & & & & & \\
\hline 12 & STAG2 & & & & & & & & \\
\hline 13 & $B M P R 2$ & & & & & & & & \\
\hline 14 & МYHIO & & & & & & & & \\
\hline 15 & $E R C C 2 *$ & & & & & & & & \\
\hline 16 & $C D H 1 *$ & & & & & & & & \\
\hline 17 & CHEK2* & & & & & & & & \\
\hline 18 & NOTCH $2 *$ & & & & & & & & \\
\hline 19 & $\operatorname{SIN} 3 A$ & & & & & & & & \\
\hline 20 & $H D A C 3$ & & & & & & & & \\
\hline 21 & CLTC* & & & & & & & & \\
\hline 22 & TCF4 & & & & & & & & \\
\hline 23 & $R A D 54 L$ & & & & & & & & \\
\hline 24 & PHOX $2 B^{*}$ & & & & & & & & \\
\hline 25 & $H L A-A$ & & & & & & & & \\
\hline 26 & NTRKI & & & & & & & & \\
\hline 27 & ERBB3 & & & & & & & & \\
\hline 28 & $A T F 2$ & & & & & & & & \\
\hline 29 & PTCHI & & & & & & & & \\
\hline 30 & NCOR 1 & & & & & & & & \\
\hline 31 & МYH9 & & & & & & & & \\
\hline 32 & TSC 2 & & & & & & & & \\
\hline 33 & ERBB4 & & & & & & & & \\
\hline 34 & PTPN12 & & & & & & & & \\
\hline 35 & KLF5 & & & & & & & & \\
\hline 36 & TSC1 & & & & & & & & \\
\hline 37 & SPTAN1 & & & & & & & & \\
\hline 38 & $H G F$ & & & & & & & & \\
\hline 39 & HSP90AB1 & & & & & & & & \\
\hline 40 & WNT5A & & & & & & & & \\
\hline 41 & MAP3K1 & & & & & & & & \\
\hline 42 & $R A X$ & & & & & & & & \\
\hline 43 & \begin{tabular}{|l|l}
$C D C 27$ \\
\end{tabular} & & & & & & & & \\
\hline 44 & NCOR2 & & & & & & & & \\
\hline
\end{tabular}


TABLE 2. List of predicted potential driver genes, their involvement in cellular pathways and previous reports on their occurrence in various cancers. Genes with bold characters are CRC driver genes listed in TCGA-COADREAD. Genes with * sign are listed in CGC as CRC driver genes

\begin{tabular}{|c|c|c|c|}
\hline Driver Genes & Pathways & Cancer types & References \\
\hline TP53* & p53 signaling & $\begin{array}{l}\text { Colorectal cancer } \\
\text { Melanoma } \\
\text { Breast Cancer }\end{array}$ & $\begin{array}{l}\text { (Petitjean et al. 2007) } \\
\text { (Ragnarsson-Olding et al. 2002) }\end{array}$ \\
\hline$F B X W 7^{*}$ & - & Colorectal cancer & (Iwatsuki et al. 2010) \\
\hline$S R G A P 3 *$ & G-protein signaling & $\begin{array}{l}\text { Colorectal cancer } \\
\text { Gastric cancer }\end{array}$ & (Huang et al. 2015) \\
\hline$K R A S^{*}$ & Ras, PI3K-AKT, MAPK signaling & $\begin{array}{l}\text { Colorectal cancer } \\
\text { Bladder cancer } \\
\text { Non-small cell lung cancer } \\
\text { Breast Cancer }\end{array}$ & $\begin{array}{l}\text { (Phipps et al. 2013) } \\
\text { (Tian et al. 2013) }\end{array}$ \\
\hline$T C F 7 L 2 *$ & Wnt signaling & Colorectal cancer & $\begin{array}{l}\text { (Slattery et al. 2009) } \\
\text { (Folsom et al. 2008) }\end{array}$ \\
\hline ARID1A* & Chromatin organization pathway & $\begin{array}{l}\text { Colorectal cancer } \\
\text { Pancreatic cancer }\end{array}$ & $\begin{array}{l}\text { (Mathur et al. 2017) } \\
\text { (Waddell et al. 2015) }\end{array}$ \\
\hline$B R A F^{*}$ & MAPK & $\begin{array}{l}\text { Colorectal cancer } \\
\text { Melanoma } \\
\text { Glioma }\end{array}$ & $\begin{array}{l}\text { (Davies et al. 2002) } \\
\text { (Fang \& Richardson 2005) } \\
\text { (Chen et al. 2014) }\end{array}$ \\
\hline ITSN1 & RET Signaling & Lung cancer & (R. Wang et al. 2015) \\
\hline CUL1 & Cell cycle pathway & Colorectal cancer & (W. Wang et al. 2015) \\
\hline$B M P R 2$ & Tgf-Beta signaling & $\begin{array}{l}\text { Colorectal cancer } \\
\text { Gastric cancer }\end{array}$ & $\begin{array}{l}\text { (Kodach et al. 2008) } \\
\text { (Park et al. 2010) }\end{array}$ \\
\hline МYH10 & - & Colorectal cancer & (Park et al. 2010) \\
\hline$E R C C 2 *$ & Nucleotide excision repair & $\begin{array}{l}\text { Breast Cancer } \\
\text { Ovary Cancer }\end{array}$ & (Rump et al. 2016) \\
\hline $\begin{array}{l}\text { CDH1* } \\
\text { CHEK2* }\end{array}$ & $\begin{array}{l}\text { Cell cycle pathway } \\
\text { p53 signaling }\end{array}$ & $\begin{array}{l}\text { Gastric cancer } \\
\text { Breast cancer }\end{array}$ & $\begin{array}{l}\text { (Rump et al. 2016) } \\
\text { (Apostolou \& Papasotiriou 2017) }\end{array}$ \\
\hline $\mathrm{NOTCH} 2 *$ & Notch Signaling & $\begin{array}{l}\text { Oesophageal cancer } \\
\text { Leukemia }\end{array}$ & $\begin{array}{l}\text { (C. Wang et al.016) } \\
\text { (Lobry et al. 2011) }\end{array}$ \\
\hline $\operatorname{SIN} 3 A$ & Thyroid hormone signaling & Breast cancer & (Lewis et al. 2016) \\
\hline$H D A C 3$ & Viral carcinogenesis & $\begin{array}{l}\text { Colorectal cancer } \\
\text { Liver Cancer }\end{array}$ & $\begin{array}{l}\text { (Bhaskara et al. 2011) } \\
\text { (Barneda-Zahonero \& Parra 2012) }\end{array}$ \\
\hline CLTC* & Lysosome & $\begin{array}{l}\text { Breast cancer } \\
\text { Renal cancer }\end{array}$ & $\begin{array}{l}\text { (Yao et al. 2015) } \\
\text { (Argani et al. 2003) }\end{array}$ \\
\hline TCF4 & Wnt signaling & Colorectal cancer & (Kim et al. 2003) \\
\hline$R A D 54 L$ & Homologous recombination & $\begin{array}{l}\text { Colorectal cancer } \\
\text { Ovary Cancer } \\
\text { prostate cancer }\end{array}$ & (Pelttari et al. 2012) \\
\hline PHOX $2 B^{*}$ & Neural Crest Differentiation & Neuroblastoma & (Bachetti et al. 2010) \\
\hline$H L A-A$ & - & Colorectal cancer & (Menon et al. 2002) \\
\hline NTRK1 & PI3K-Akt signaling pathway & Colorectal cancer & $\begin{array}{l}\text { (Créancier et al. 2015) } \\
\text { (Iacopetta et al. 2006) }\end{array}$ \\
\hline$E R B B 3$ & MAPK Signaling & $\begin{array}{l}\text { Breast cancer } \\
\text { Ovarian cancer } \\
\text { prostate cancer }\end{array}$ & $\begin{array}{l}\text { (Ma et al. 2014) } \\
\text { (Sithanandam \& Anderson 2008) }\end{array}$ \\
\hline ATF2 & PI3K-Akt signaling & $\begin{array}{l}\text { Renal cell carcinoma } \\
\text { skin cancer }\end{array}$ & $\begin{array}{l}\text { (Wu et al. 2016) } \\
\text { (Bhoumik et al. 2008) }\end{array}$ \\
\hline
\end{tabular}


Continued TABLE 2

\begin{tabular}{llll}
\hline Driver Genes & Pathways & Cancer types & References \\
\hline PTCH1 & Hedgehog signaling & gastric cancer & (X. De Wang et al. 2013) \\
NCOR1 & Endocrine resistance signaling & Thyroid cancer & (Fozzatti et al. 2013) \\
$M Y H 9$ & regulation of cytoskeleton & Lung cancer & (Katono et al. 2015) \\
$T S C 2$ & p53 signaling pathway & Breast cancer & (Mehta et al. 2011) \\
ERBB4 & MAPK signaling & Colon cancer & (Williams et al. 2015) \\
$P T P N 12$ & - & Liver cancer & (Luo Lam 2013) \\
KLF5 & - & Breast Cancer & (Jia et al. 2016) \\
$T S C 1$ & mTOR signaling pathway & Bladder cancer & (Metha et al. 2011) \\
SPTAN1 & Tgf-Beta Signaling & Oral Cancer & (Prasad et al. 2016) \\
$H G F$ & MAPK signaling pathway & Esophageal cancer & (Ren et al. 2005) \\
$H S P 90 A B 1$ & PI3K-Akt signaling & Gastrointestinal cancer & (Moser et al. 2009) \\
WNT5A & Transcription AR nuclear signaling & Breast Cancer & (Prasad et al. 2016) \\
$M A P 3 K 1$ & MAPK signaling & Prostate cancer & (Pham et al. 2013) \\
& & Gastric cancer & \\
RAX & - & - & - \\
CDC27 & Cell cycle pathway & Colorectal cancer & (Qiu et al. 2016) \\
& & Breast cancer & (Qiu et al. 2016) \\
NCOR2 & Notch signaling & Breast cancer & (Van Agthoven et al. 2009) \\
STAG2 & Cell cycle pathway & Bladder cancer & (Black 2014)
\end{tabular}

A total of 21 pathways have been identified related to the predicted CRC driver genes (Table 3). The information on the pathways where these genes were involved were obtained from KEGG database and literature searching. The result has suggested the involvement of driver genes in dysregulating the multiple pathways causing to the colorectal cancer carcinogenesis. The highest number of pathways might be dysregulated by driver genes were found in patient $\mathrm{C} 474$, followed by patient $\mathrm{C} 414$ and patient C373.

P53 signaling pathway shows positive signal of perturbation that affects 7 out of 8 patients in this study. Genes TP53, CHEK 2 and TSC 2 are predicted to drive colorectal carcinogenesis and related with p53 signaling pathway. Gene TP53 activated by CHEK2, CHEKI and $A T M$ to regulate various cell activities, meanwhile, TSC2 regulated by $T P 53$ to inhibit mTOR signaling pathway (Figure 3). Activation of mTOR signaling pathway will lead to increase in cell proliferation (Harris \& Levine 2005; Li et al. 2015; Shao et al. 2001).

Driver gene NCORI was found in the endocrine resistance pathway were predicted to be dysregulated in six patients (C187, C194, C373, C404, C414, and C474). In normal condition, NCORI forms a complex with ESRI to inhibit the genes that involved in cell proliferation (Figure 4).

Driver genes such as KRAS, NTRK1, ERBB3, ATF2, $E R B B 4$, and HSP90AB1 were found in patient C273, C404, C414, C449, and C474 and they were involved in Phosphoinositide 3-kinase-AKT (PI3K-AKT) pathway (Figure 5). PI3K-AKT signaling pathway is involved in mechanisms of growth stimulation, increase cellular proliferation and reduce apoptosis. Crucial component in PI3K-AKT is AKT3 is linked with driver gene, TSC2 regulator of mammalian target of rapamycin (mTOR) signaling pathway. mTOR signaling pathway has role in cell growth and proliferation.

MAPK signaling pathway was predicted as one of the highly dysregulated pathways in patient C273, C404, $\mathrm{C} 414, \mathrm{C} 449$, and C474. Three genes were involved in this pathway, i.e. $B R A F, E R B B 3$, and MAP3K1. ERBB 3 encodes a member of RTK (Receptor Tyrosine Kinase) and RTK activation initiates MAPK signaling pathway which then leads to the activation of another key signaling molecules i.e. Ras, which was encoded by KRAS gene. BRAF encodes for B-Raf protein; one of regulator sin MAPK-ERK signaling pathway that involved in cell proliferation and differentiation whilst MAP $3 K 1$ encodes for MEKK1 protein which is a key regulator in the MAPK-JNK signaling pathway. MEKK1 regulates proliferation, differentiation and inflammation (Fang \& Richardson 2005; Ma et al. 2014).

\section{CONCLUSION}

From this study, 44 unique driver genes have been predicted in eight Malaysian colorectal cancer patients through extensive customized bioinformatics analysis along with the identification of 21 unique pathways that were found to be related with those driver genes. Amongst the identified pathways, that potentially perturbed driven by mutation of regulators are p53 signaling, PI3K-AKT, MAPK and endocrine resistance were predicted to be potentially perturbed driven by the mutation of regulators. Prediction of cancer driver genes will give detailed insight on the mechanisms of cancer development and a crucial step for targeted therapy process. 
TABLE 3. Type of pathways that were associated with driver genes in each patient

p53 signaling pathway

PI3K-AKT signaling pathway

Wnt Signaling pathway

$\operatorname{tgf}-\beta$ signaling pathway

G-protein signaling

MAPK signaling pathway

RET signaling pathway

Chromatin Organization

Nucleotide excision repair

Cell cycle pathway

Notch Signaling

Thyroid hormone signaling

Viral carcinogenesis

Homologous recombination

Neural Crest Differentiation

Hedgehog Signaling Pathway

Endocrine resistance

Tight junction

Regulation of cytoskeleton mTOR signaling pathway

Transcription AR nuclear signaling

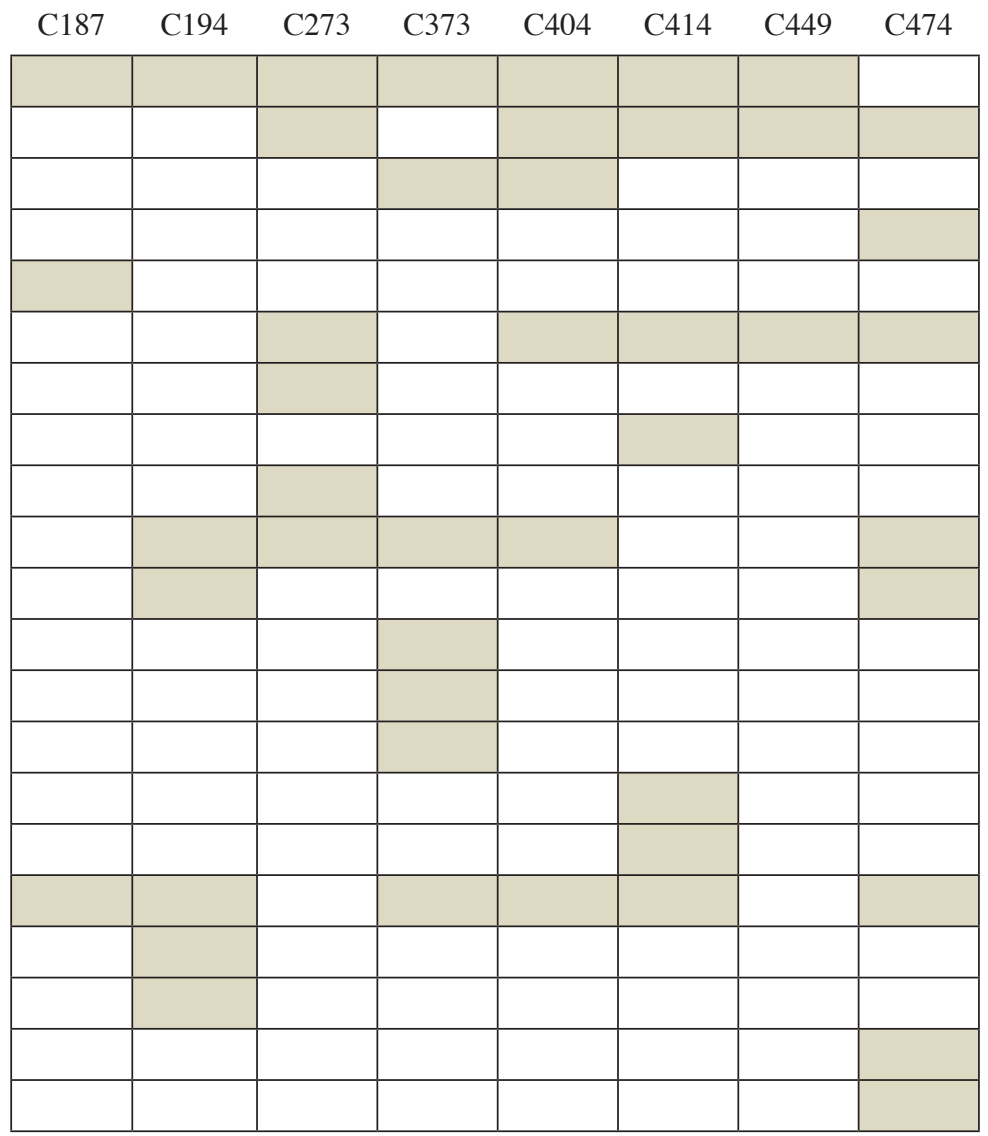

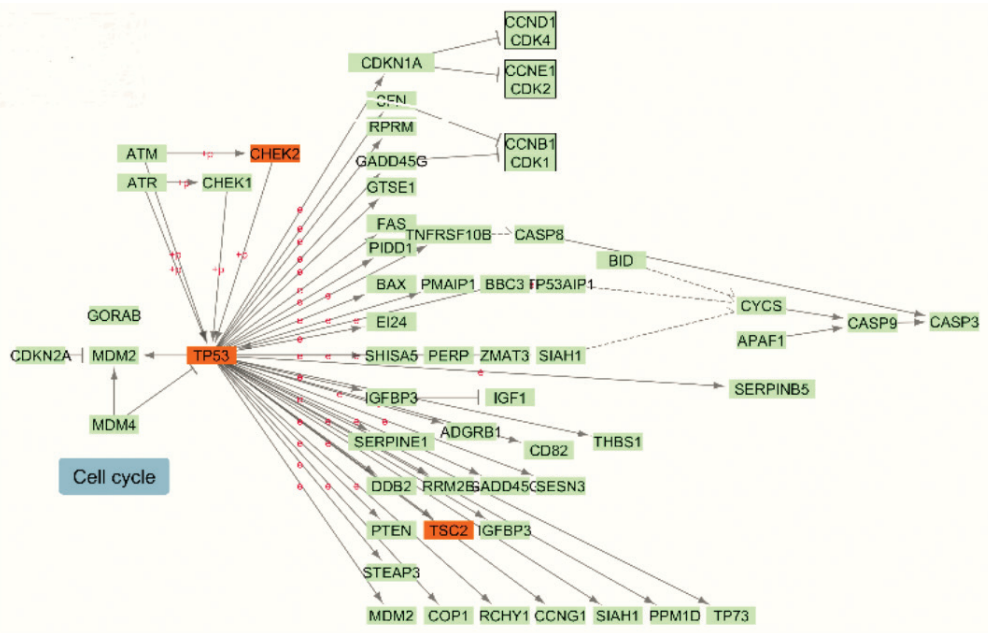

FIGURE 3 . The involvement of the predicted drivers TP53, CHEK2 and TSC2 in p53 signaling pathway

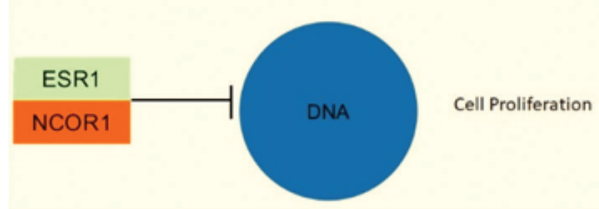

FIGURE 4. NCOR1 in endocrine resistance pathways 


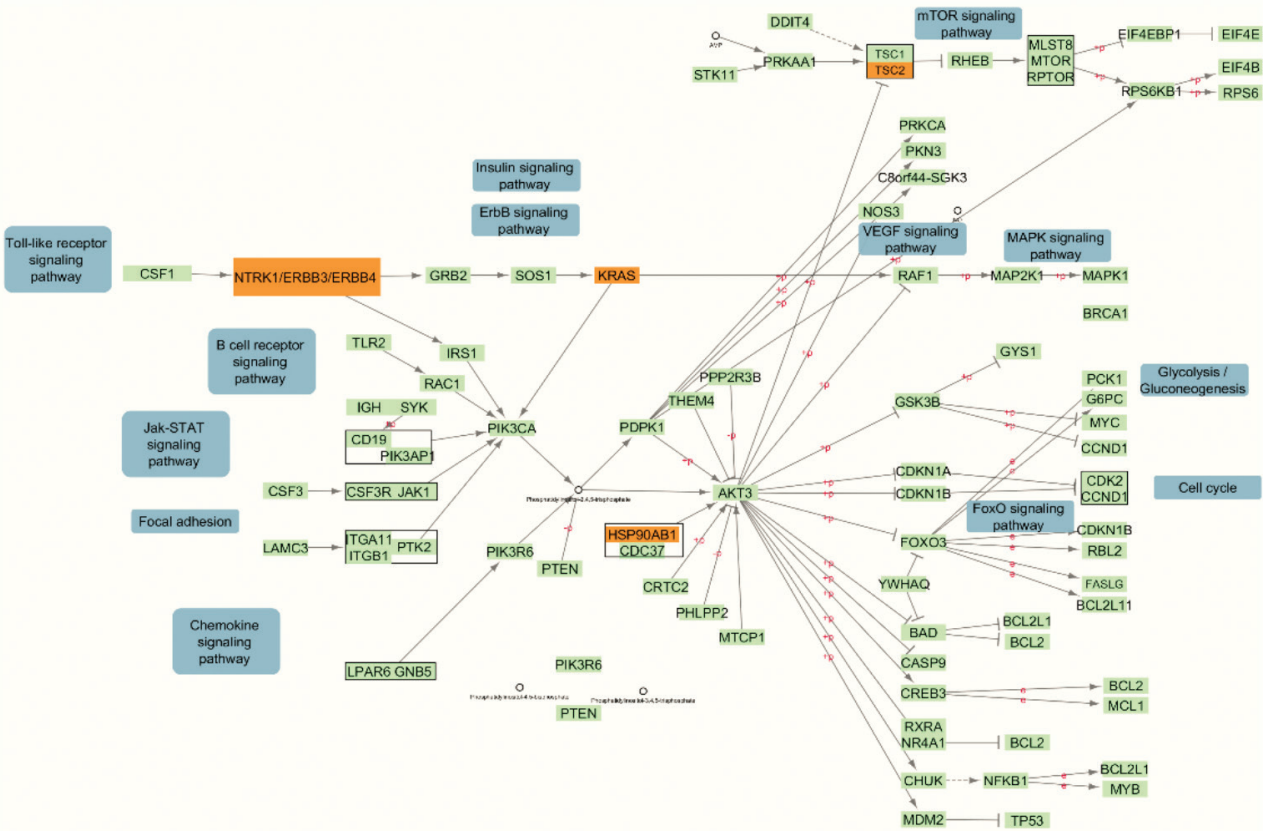

FIGURE 5. Location of NTRK1 , ERBB3, ERBB4, KRAS, TSC2 and HSP9OAB1 in PI3K-AKT signaling pathways

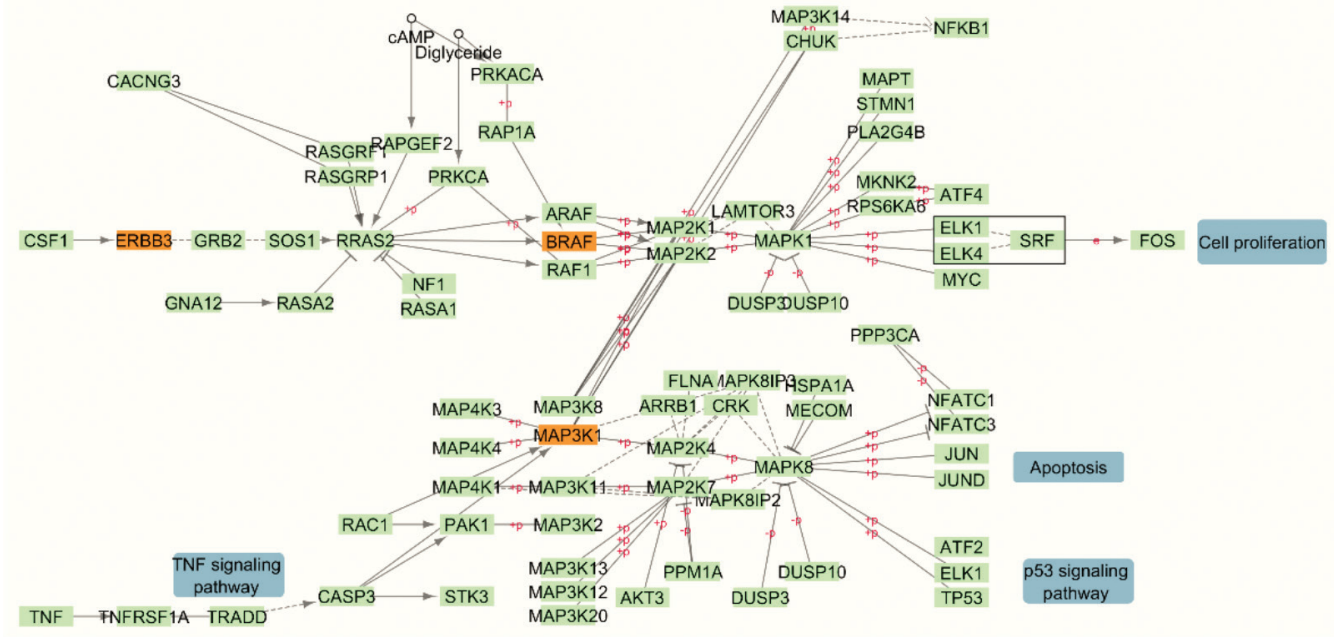

FIGURE 6. ERBB3, BRAF and MAP3K1 in MAPK signaling pathways

\section{ACKNOWLEDGEMENTS}

This work was supported by LRGS/2014/UKM-UKM/K/04 awarded to Assoc. Prof. Dr. Zeti Azura Mohamed Hussein by the Ministry of Higher Education, Malaysia.

\section{REFERENCES}

Adzhubei, I., Jordan, D.M. \& Sunyaev, S.R. 2015. Predicting functional effect of human missense mutations using PolyPhen-2. Current Protocols in Human Genetics Unit 7.20. Alberts, B. 2008. Tumor suppressor genes and oncogenes: Genes that prevent and cause cancer. In Molecular Biology of the Cell, 5th ed., edited by Alberts, B., Johnson, A., Lewis, J., Raff, M., Roberts, K. \& Walter, P. Garland Science. pp. 1230-1256.
Apostolou, P. \& Papasotiriou, I. 2017. Current perspectives on CHEK2 mutations in breast cancer. Breast Cancer: Targets and Therapy 9: 331-335.

Argani, P., Lui, M.Y., Couturier, J., Bouvier, R., Fournet, J.C. \& Ladanyi, M. 2003. A novel CLTC-TFE3 gene fusion in pediatric renal adenocarcinoma with $\mathrm{t}(\mathrm{X} ; 17)(\mathrm{p} 11.2 ; \mathrm{q} 23)$. Oncogene 22(34): 5374-5378.

Bachetti, T., Di Paolo, D., Di Lascio, S., Mirisola, V., Brignole, C., Bellotti, M. \& Caffa, I. 2010. PHOX2B-mediated regulation of ALK expression: In vitro identification of a functional relationship between two genes involved in neuroblastoma. PLOS ONE 5(10): e13108.

Barneda-Zahonero, B. \& Parra, M. 2012. Histone deacetylases and cancer. Molecular Oncology 6(6): 579-589.

Bhaskara, S., Knutson, S.K., Jiang, G., Chandrasekharan, M.B., Wilson, A.J., Zheng, S. \& Yenamandra, A. 2011. Role for 
histone deacetylase 3 in maintenance of genome stability Genome Stability 18(5): 436-447.

Bhoumik, A., Fichtman, B., DeRossi, C., Breitwieser, W., Kluger, H.M., Davis, S. \& Subtil, A. 2008. Suppressor role of activating transcription factor 2 (ATF2) in skin cancer. Proceedings of the National Academy of Sciences 105(5): 1674-1679.

Black, P. 2014. Frequent truncating mutations of STAG2 in bladder cancer. Urology 83(4): 691-692.

Chen, Y., McGee, J., Chen, X., Doman, T.N., Gong, X., Zhang, Y. \& Hamm, N. 2014. Identification of druggable cancer driver genes amplified across TCGA datasets. PLOS ONE 9(5): e98293.

Cho, A., Shim, J.E., Kim, E., Supek, F., Lehner, B .\& Lee, I. 2016. MUFFINN: Cancer gene discovery via network analysis of somatic mutation data. Genome Biology 17(1): 129.

Chye, G.L.C., Rampal, S. \& Yahaya, H. 2008. Cancer incidence in Peninsular Malaysia 2003-2005. National Cancer Registry. pp. 53-57.

Créancier,L., Vandenberghe, I., Gomes, B., Dejean, C., Blanchet, J.C., Meilleroux, J. \& Guimbaud, R. 2015. Chromosomal rearrangements involving the NTRK1 gene in colorectal carcinoma. Cancer Letters 365(1): 107-111.

Davies, H., Bignell, G.R., Cox, C., Stephens, P., Edkins, S., Clegg, S. \& Teague, J. 2002. Mutations of the BRAF gene in human cancer. Nature 417(6892): 949-954.

Dees, N.D., Zhang, Q., Kandoth, C., Wendl, M.C., Schierding, W., Koboldt, D.C.\& Mooney, T. B. 2012. MuSiC: Identifying mutational significance in cancer genomes. Genome Research 22(8): 1589-1598.

Fang, J.Y. \& Richardson, B.C. 2005. The MAPK signalling pathways and colorectal cancer. Lancet Oncology 6(5): 322-327.

Folsom, A.R., Pankow, J.S., Peacock, J.M., Bielinski, S.J., Heiss, G. \& Boerwinkle, E. 2008. Variation in TCF7L2 and increased risk of colon cancer: The atherosclerosis risk in communities (ARIC) study. Diabetes Care 31(5): 905-909.

Foo, J., Liu, L.L., Leder, K., Riester, M., Iwasa, Y., Lengauer, C. \& Michor, F. 2015. An evolutionary approach for identifying driver mutations in colorectal cancer. PLoS Computational Biology 11(9): 1-19.

Fozzatti, L., Park, J.W., Zhao, L., Willingham, M.C. \& Cheng, S.Y. 2013. Oncogenic actions of the nuclear receptor corepressor (NCOR1) in a mouse model of thyroid cancer. PLOS ONE 8(6): 1-10.

Harris, S.L. \& Levine, A.J. 2005. The p53 pathway: Positive and negative feedback loops. Oncogene 24(17): 2899-2908.

Huang, T., Kang, W., Cheng, A.S.L., Yu, J. \& To, K.F. 2015. The emerging role of slit-robo pathway in gastric and other gastro intestinal cancers. BMC Cancer 15(1): 1-9.

Iacopetta, B., Russo, A., Bazan, V., Dardanoni, G., Gebbia, N., Soussi, T. \& Kerr, D. 2006. Functional categories of TP53 mutation in colorectal cancer: Results of an international collaborative study. Annals of Oncology 17(5): 842-847.

Iwatsuki, M., Mimori, K., Lshii, H., Yokobori, T., Takatsuno, Y., Sato, T. \& Toh, H. 2010. Loss of FBXW7, a cell cycle regulating gene, in colorectal cancer: Clinical significance. International Journal of Cancer 126(8): 1828-1837.

Jia, L., Zhou, Z., Liang, H., Wu, J., Shi, P., Li, F. \& Wang, Z. 2016. KLF5 promotes breast cancer proliferation, migration and invasion in part by upregulating the transcription of TNFAIP2. Oncogene 35(16): 2040-2051.
Kanner, J. 2007. Dietary advanced lipid oxidation endproducts are risk factors to human health. Molecular Nutrition and Food Research 51(9): 1094-1101.

Katono, K., Sato, Y., Jiang, S.X., Kobayashi, M., Nagashio, R., Ryuge, S. \& Fukuda, E. 2015. Prognostic significance of MYH9 expression in resected non-small cell lung cancer. Plos One 10(3): e 0121460

Kim, P.J., Plescia, J., Clevers, H., Fearon, E.R. \& Altieri, D.C 2003. Surviving and molecular pathogenesis of colorectal cancer. Lancet 362(9379): 205-209.

Kodach, L.L., Wiercinska, E., de Miranda, N.F.C.C., Bleuming, S.A., Musler, A.R., Peppelenbosch, M.P. \& Dekker, E. 2008. The bone morphogenetic protein pathway is inactivated in the majority of sporadic colorectal cancers. Gastroenterology 134(5): 1332-1341.

Kwong,L.N. \& Dove, W.F. 2009. APC and its modifiers in colon cancer. Advances in Experimental Medicine and Biology 656: 85-106.

Leiserson, M.D.M., Vandin, F., Wu, H.T., Dobson, J.R., Eldridge, J.V., Thomas, J.L. \& Papoutsaki,A. 2014. Pan-cancer network analysis identifies combinations of rare somatic mutations across pathways and protein complexes. Nature Genetics 47(2): 106-114

Lewis, M.J., Liu, J., Falk Libby, E., Lee, M., Crawford, N.P.S.\& Hurst, D.R. 2016. SIN3A and SIN3B differentially regulate breast cancer metastasis. Oncotarget 7(48): 78713-78725.

Li, X.L., Zhou, J., Chen, Z.R. \& Chng, W.J. 2015. p53 mutations in colorectal cancer: Molecular pathogenesis and pharmacological reactivation. World Journal of Gastroenterology 21(1): 84-93.

Lobry, C., Oh, P. \& Aifantis, I. 2011. Oncogenic and tumor suppressor functions of Notch in cancer: it's NOTCH what you think. The Journal of Experimental Medicine 208(10): 1931-1935.

Louis, P., Hold, G.L. \& Flint, H.J. 2014. The gut microbiota, bacterial metabolites and colorectal cancer. Nature Reviews Microbiology 12(10): 661-672.

Luo, S.Y.\& Lam, D.C. 2013. Oncogenic driver mutations in lung cancer. Translational Respiratory Medicine 1(1): 6.

Ma, J., Lyu, H., Huang, J. \& Liu, B. 2014. Targeting of erbB3 receptor to overcome resistance in cancer treatment. Molecular Cancer 13(1): 1-9.

Marx, V. 2014. Cancer genomes: Discerning drivers from passengers. Nature Methods 11(4): 375-379.

Mathur, R., Alver, B.H., San Roman, A.K., Wilson, B.G., Wang, X., Agoston, A.T. \& Park, P.J. 2017. ARID1A loss impairs enhancer-mediated gene regulation and drives colon cancer in mice. Nature Genetics 49(2): 296-302.

Mehta, M.S., Vazquez, A., Kulkarni, D.A., Kerrigan, J.E., Atwal, G., Metsugi, S. \& Toppmeyer, D.L. 2011. Polymorphic variants in TSC1 and TSC 2 and their association with breast cancer phenotypes. Breast Cancer Research and Treatment 125(3): 861-868

Menon, A.G., Morreau, H., Tollenaar, R.A.E.M., Alphenaar, E., Van Puijenbroek, M., Putter, H. \& Janssen-van Rhijn, C.M 2002. Downregulation of HLA-A expression correlates with a better prognosis in colorectal cancer patients. Laboratory Investigation 82(12): 1725-1733.

Moser, C., Lang, S.A. \& Stoeltzing, O. 2009. Heat-shock protein 90 (Hsp90) as a molecular target for therapy of gastrointestinal cancer. Anticancer Research 29(6): 2031-2042.

O'Keefe, S .J.D. 2016. Diet, microorganisms and their metabolites and colon cancer. Nature Reviews Gastroenterology \& Hepatology 13(12): 691-706. 
Park, S.W., Hur, S.Y., Yoo, N.J. \& Lee, S.H. 2010. Somatic frameshift mutations of bone morphogenic protein receptor 2 gene in gastric and colorectal cancers with microsatellite instability. Apmis 118(11): 824-829.

Pelttari, L.M., Kiiski, J., Nurminen, R., Kallioniemi, A., Schleutker, J., Gylfe, A. \& Aaltonen, L.A. 2012. A finnish founder mutation in RAD51D: Analysis in breast, ovarian, prostate, and colorectal cancer. Journal of Medical Genetics 49(7): 429-432.

Petitjean, A., Achatz, M.I.W., Borresen-Dale, A.L., Hainaut, P. \& Olivier, M. 2007. TP53 mutations in human cancers: Functional selection and impact on cancer prognosis and outcomes. Oncogene 26(15): 2157-2165.

Pham, T.T., Angus, S.P. \& Johnson, G.L. 2013. MAP3K1: Genomic alterations in cancer and function in promoting cell survival or apoptosis. Genes and Cancer 4(11-12): 419-426.

Phipps, A.I., Buchanan, D.D., Makar, K.W., Win, A.K., Baron, J.A., Lindor, N.M. \& Potter, J.D. 2013. KRAS-mutation status in relation to colorectal cancer survival: The joint impact of correlated tumour markers. British Journal of Cancer 108(8): 1757-1764.

Prasad, C.P., Chaurasiya, S.K., Guilmain, W. \& Andersson, T. 2016. WNT5A signaling impairs breast cancer cell migration and invasion via mechanisms independent of the epithelialmesenchymal transition. Journal of Experimental and Clinical Cancer Research 35(1): 1-15.

Qiu, L., Wu, J., Pan, C., Tan, X., Lin, J., Liu, R. \& Chen, S. 2016. Downregulation of CDC27 inhibits the proliferation of colorectal cancer cells via the accumulation of p21Cip1/ Waf1. Cell Death \& Disease 7(651): e2074.

Radzi, M., Hassan, A., Ismail, I., Azri, M., Suan, M., Ahmad, F. \& Khamizar, W. 2016. Incidence and mortality rates of colorectal cancer in Malaysia. Epidemiol. Health 38: 6-10.

Ragnarsson-Olding, B.K., Karsberg, S., Platz, A. \& Ringborg, U.K. 2002. Mutations in the TP53 gene in human malignant melanomas derived from sun-exposed skin and unexposed mucosal membranes. Melanoma Research 12(5): 453-463.

Ren, Y., Cao, B., Law, S., Xie, Y., Lee, P.Y., Cheung, L. \& Chen, Y. 2005. Hepatocyte growth factor promotes cancer cell migration and angiogenic factors expression: A prognostic marker of human esophageal squamous cell carcinomas. Clinical Cancer Research 11(17): 6190-6197.

Rivlin, N., Brosh, R., Oren, M. \& Rotter, V. 2011. Mutations in the p53 tumor suppressor gene: Important milestones at the various steps of tumorigenesis. Genes and Cancer 2(4): 466-474.

Rump, A., Benet-Pages, A., Schubert, S., Kuhlmann, J.D., Janavičius, R., Macháčková, E. \& Foretová, L. 2016. Identification and functional testing of ERCC2 mutations in a multi-national cohort of patients with familial breast- and ovarian cancer. PLoS Genetics 12(8): 1-18.

Ryan-Harshman, M. \& Aldoori, W. 2007. Diet and colorectal cancer: Review of the evidence. Canadian Family Physician Médecin de Famille Canadien 53(11): 1913-1920.

Shao, L., Lai, M. \& Huang, Q. 2001. Mutagen sensitivity and p53 expression in colorectal cancer in China. Postgraduate Medical Journal 77: 713-716.

Sim, N.L., Kumar, P., Hu, J., Henikoff, S., Schneider, G. \& Ng, P.C. 2012. SIFT web server: Predicting effects of amino acid substitutions on proteins. Nucleic Acids Research 40(W1): W452-W457.

Sithanandam, G. \& Anderson, L.M. 2008. The ERBB3 receptor in cancer and cancer gene therapy. Cancer Gene Therapy 15(7): 413-448.
Slattery, M.L., Folsom, A.R., Wolff, R., Herrick, J., Caan, B.J. \& Potter, J.D. 2009. Tumor markers and rectal cancer: Support for an inflammation-related pathway. International Jourmal of Cancer 17(4): 978-982.

Tan, C. \& Du, X. 2012. KRAS mutation testing in metastatic colorectal cancer. World Journal of Gastroenterology 18(37): 5171-5180

Tian, S., Simon, I., Moreno, V., Roepman, P., Tabernero, J., Snel, M. \& Veer, L. 2013. A combined oncogenic pathway signature of BRAF, KRAS and PI3KCA mutation improves colorectal cancer classification and cetuximab treatment prediction. Gut 62(4): 540-549.

Tokheim, C., Papadopoulis, N., Kinzler, K.W., Vogelstein, B. \& Karchin, R. 2016. Evaluating the evaluation of cancer driver genes. bioRxiv 113(50): 060426.

Van Agthoven, T., Sieuwerts, A.M., Veldscholte, J., Meijer-Van Gelder, M.E., Smid, M., Brinkman, A. \& Den Dekker, A.T. 2009. CITED2 and NCOR2 in anti-oestrogen resistance and progression of breast cancer. British Journal of Cancer 101(11): 1824-1832.

Waddell, N., Pajic, M., Patch, A., Chang, D.K., Kassahn, K.S., Bailey, P. \& Johns, A.L. 2015. Whole genomes redefine the mutational landscape of pancreatic cancer. Nature 518(7540): 495-501.

Wang, C., Li, Q., Liu, F., Chen, X., Liu, B., Nesa, E.U., Guan, S., Han, L., Tan, B., Wang, N., Wang, X., Song, Q., Jia, Y., Wang, J., Lu, M. \& Chen, Y. 2016. Notch2 as a promising prognostic biomarker for oesophageal squamous cell carcinoma. Scientific Reports 6 (25722): 1-10.

Wang, X.D., Inzunza, H., Chang, H., Qi, Z., Hu, B., Malone, D. \& Cogswell, J. 2013. Mutations in the hedgehog pathway genes SMO and PTCH1 in human gastric tumors. PLoS ONE 8(1): 1-8.

Wang, R., Zhang, Y., Pan, Y., Li, Y., Hu, H. \& Cai, D. 2015. Comprehensive investigation of oncogenic driver mutations in Chinese non-small cell lung cancer patients. Oncotarget 6(33): 1-9.

Wang, W., Chen, Y., Deng, J., Zhou, J., Gu, X., Tang, Y. \& Zhang, G. 2015. Cullin1 is a novel prognostic marker and regulates the cell proliferation and metastasis in colorectal cancer. Journal of Cancer Research and Clinical Oncology 141(9): 1603-1612.

Williams, C.S., Bernard, J.K., Beckler, M.D., Almohazey, D., Washington, M.K., Smith, J.J. \& Frey, M.R. 2015. ERBB4 is over-expressed in human colon cancer and enhances cellular transformation. Carcinogenesis 36(7): 710-718.

Wu, D.S., Chen, C., Wu, Z.J., Liu, B., Gao, L., Yang, Q. \& Chen, W. 2016. ATF2 predicts poor prognosis and promotes malignant phenotypes in renal cell carcinoma. Journal of Experimental and Clinical Cancer Research 35(1): 1-11.

Yao, F., Zhang, C., Du, W., Liu, C. \& Xu, Y. 2015. Identification of gene-expression signatures and protein markers for breast cancer grading and staging. PLOS ONE 10(9): 1-17.

Zhan, T., Rindtorff, N. \& Boutros, M. 2017. Wnt signaling in cancer. Oncogene 36(11): 1461-1473.

Centre for Bioinformatics Research Institute of Systems Biology (INBIOSIS)

Universiti Kebangsaan Malaysia

43600 UKM Bangi, Selangor Darul Ehsan Malaysia 
*Corresponding author; email: norazlannm@ukm.edu.my

Received: 30 May 2018

Accepted: 14 September 2018 